2021-04-30

\title{
Designing A Module In Entrepreneurship For Product Design Students
}

PJ White

IT Carlow, pj.white@itcarlow.ie

Con Kennnedy

TUDublin, con.kennedy@tudublin.ie

Follow this and additional works at: https://arrow.tudublin.ie/desigpart

Part of the Art and Design Commons

\section{Recommended Citation}

White, P.J., \& Kennedy, C. (2021). Designing A Module In Entrepreneurship For Product Design Students. Industry and Higher Education pg. 1-10. doi:10.1177/09504222211013742.

This Article is brought to you for free and open access by the Design and Printing at ARROW@TU Dublin. It has been accepted for inclusion in Academic Articles by an authorized administrator of ARROW@TU Dublin. For more information, please contact arrow.admin@tudublin.ie, aisling.coyne@tudublin.ie, gerard.connolly@tudublin.ie. 


\title{
Designing a module in entrepreneurship for product design students
}

Industry and Higher Education

(C) The Author(s) 2021

Article reuse guidelines: sagepub.com/journals-permissions DOI: 10.1 I 77/0950422221 I013742 journals.sagepub.com/home/ihe

(3)SAGE

\section{P.J. White}

Institute of Technology Carlow, Ireland

\section{Con Kennedy}

TU Dublin, Ireland

\begin{abstract}
Creative problem-solving has been identified as one of the most critical future-proof skillsets we can develop in our society. When educating future designers, entrepreneurship skills are now considered essential; however, designers find it difficult to establish themselves as entrepreneurs. Therefore, graduate designers are increasingly in need of these skills to complement their creative ability. This paper offers information to academic institutions looking to implement entrepreneurship modules in existing design and creative programmes. The paper seeks to understand the entrepreneurship skills required for product design graduates through a case study. Current teaching practice is described, and interviews and co-design sessions with relevant stakeholders are conducted to inform future entrepreneurship education for product design students. From these findings, a module descriptor entitled 'Entrepreneurship for Designers' was created for an existing programme and delivered through both practice and theory. This module is intended to provide an understanding of the entrepreneurship process and to offer students the confidence to pursue design-related ventures post-graduation.
\end{abstract}

\section{Keywords}

Co-design, creative problem-solving, design, design entrepreneurship, entrepreneurship, product design

\section{Product design and entrepreneurship}

Over the last decade, there has been a growing acknowledgement of the need for innovation and creative problemsolving skills across enterprise sectors. This need expands beyond traditional creative sectors, and the value of designled methodologies for problem-solving is now being recognised more broadly (Head, 2019). Creative problem-solving has been identified as one of the most critical future-proof skillsets we can develop in our society and is seen as a means to identify opportunities for positive change (Robinson, 2011). Product design is primarily a creative problemsolving discipline. Product designers create artefacts or services by understanding people's behaviour and physical attributes, using brainstorming, ideation, sketching, model making and engineering skills to problem-solve.

Creative processes such as product design are complementary to entrepreneurship processes in many ways. Scott and Venkataraman describe entrepreneurship as a process by which opportunities to create future goods and services are discovered and evaluated (2000). Similarly, Barron states that creativity is an ability to respond adaptively to the needs for new approaches and new products, hence bringing something new into existence purposefully (1988). Furthermore, Torrance explains that creativity can be the vehicle for entrepreneurial activity by sensing problems, forming ideas of hypotheses, testing and modifying them and communicating results (1963).

According to Gunes, design entrepreneurship is ' . . . about producing and marketing the intellectual properties of a viable concept in terms of assuming risks, financing and managing' (2012: 61). Design is increasingly used by entrepreneurs not only in developing products for start-ups but also in designing future strategies (Gaynor et al., 2018). At a national level, the Irish Government has recognised the importance of design for new enterprises and the explicit need for design

\section{Corresponding author:}

P.J. White, DesignCORE, Department of Humanities, Institute of Technology Carlow, Kilkenny Rd, Carlow, Ireland R93V960.

Email: pj.white@itcarlow.ie 
graduates has been outlined in several national reports (DCCoI, 2015; Innovation Taskforce, 2010). These reports recognise design and entrepreneurship as required future 'transversal skills' for graduates together with creativity, innovation, critical and analytical thinking, teamwork, communication and business acumen (O Sullivan, 2019).

However, entrepreneurship skill deficits and the requirement for curriculum development are identified in several other reports on the Irish design sector. Enterprise Ireland (1999) noted that there was a greater need for an emphasis on the entrepreneurship aspects of design and acknowledged that, although most design education programmes had some business-related subjects, students needed to develop their entrepreneurship skills further. Intertrade Ireland (2009) found that design enterprises needed to develop a competitive advantage to facilitate entry to new markets, and that there was no evidence of long-term business planning. The Department of Jobs, Enterprise and Innovation (DJEI, 2016) recognised a need for improved business skills among designers and specifically identified a role for educational institutions in developing appropriate curricula and programmes to address this need. Similar skill deficits in the design sector have also been identified internationally (Design Council, 2005; Design Council and DBA, 2005) - so that issues identified with design education do not exclusively relate to the Irish sector.

There is a clear need for specific training in entrepreneurship in undergraduate design programmes. Gunes (2012) states that teaching entrepreneurship skills in design programmes is as essential as teaching any design skill, because it helps to prepare students for the business world when they graduate. However, according to Gaiardo, designers struggle to establish themselves in the managerial and strategic entrepreneurship process (2019). Gunes (2012) offers an overview of what could be covered in a design entrepreneurship module for product designers - for example, 'Basics of Economics', 'Competency Awareness', 'Creative Application and Business Models'. Some of these topics are covered in the learning outcomes of other design disciplines (for example, Visual Communication Design TU Dublin, 2021). However, little research has been completed to understand specific content and learning outcomes for an entrepreneurship module for product design students.

\section{Aims and objectives}

The aim of this study is to begin to address the entrepreneurship skill deficit in product design education by designing a specific module. The objectives are to:

(1) gain an understanding of learning outcomes and content for an entrepreneurship module for product design students; and

(2) with this understanding, to create a new module descriptor for implementation in an undergraduate design programme.
Therefore, this paper seeks to answer the question: what should be included in an 'Entrepreneurship for Product Design' module? What are the aims, learning outcomes, syllabus content, module assessment and teaching and learning strategies? Through a case study, the paper seeks to understand this content, creating a new module descriptor for implementation in an existing undergraduate design programme.

\section{The case study}

The higher education institution in this case study has delivered programmes in design since the early 1970s, and its undergraduate programmes are in Industrial and Product Design. In December 2013 it opened a purpose-built research centre with the discipline of design as one of its main research functions (Dempsey and White, 2015; White and Deevy, 2020). The Design School together, with the commercialisation office, offer a platform for graduates to develop product design innovations through government grant funding. This activity, in conjunction with graduates, is central to the future research agenda of the Institute, thus creating a research centre that is both 'industry-facing' and innovation-led.

Recently, the commercialisation office, in partnership with the National Enterprise Board, has commenced working with final-year Product Design undergraduates to bring final-year projects to stages of commercialisation. This is seen as an exciting and much-needed venture to help students develop product innovations post-graduation. Additionally, it is an opportunity for the Institute to create knowledge through practice-based research, patents and otherwise. However, for such projects to be successful, it has been identified that entrepreneurship learning should be introduced for undergraduate design students. The learning approach to design at the Institute is both discovery- and experiential-based (Bruner, 1961; Kolb, 1984). Students deal with ambiguity and are allowed to explore, discover and experiment creatively within a given problem area in a studio-based environment. By learning design skills in this manner, they inherently learn to become 'Design Thinkers'. Design Thinking can be described as: 'the thought and behaviour process created from design practice' (White, 2012: 10). Design Thinking has opened and democratised the process of design to other disciplines and wider problems, rather than just creating physical artefacts, and therefore further aligns design with entrepreneurship. Its application is now being heralded as more important than the act of designing itself (Brown, 2009; White, 2013) and is being used to address diverse complex issues from politics to education and social change (Vrkljan et al., 2019; White et al. 2020; Marston, Shore and White, 2020).

The product design students in this case study are required to apply the Design Thinking process across their 4 years of study. In reviewing the learning outcomes and 
Table I. Review of course learning outcomes and skills in the Product Design programme.

\begin{tabular}{|c|c|}
\hline & Learning outcomes and skills \\
\hline $\begin{array}{l}\text { Year I } \\
\text { Skills Acquisition }\end{array}$ & $\begin{array}{l}\text { Students learn to engage with studio-based education through creative problem-solving and acquire } \\
\text { the foundation skills of designing. They achieve this by investigation and experimentation through } \\
\text { practice and learning from failure. They gain an appreciation of design and Design Thinking and } \\
\text { culture, and learn skills in sketching, model making, visual communications, management and } \\
\text { material manufacture. }\end{array}$ \\
\hline $\begin{array}{l}\text { Year } 2 \\
\quad \text { Skills Application }\end{array}$ & $\begin{array}{l}\text { Students gain a deeper appreciation of Design Thinking. They develop and further apply their skills of } \\
\text { creativity through problem-based learning and develop their design identity. In this year they } \\
\text { develop skills in professionalism, computer-aided design, presentation techniques, new product } \\
\text { development and marketing. }\end{array}$ \\
\hline $\begin{array}{l}\text { Year } 3 \\
\text { Design Theory, Practice and } \\
\text { Reflection }\end{array}$ & $\begin{array}{l}\text { Students deal with wider social issues and understand how Design Thinking can have an impact on } \\
\text { real-world problems. They continually apply the skills learned in years I and } 2 \text { and use reflection to } \\
\text { document learning. They delve deeper into design research collaboration and user-centred design. }\end{array}$ \\
\hline $\begin{array}{l}\text { Year } 4 \\
\text { Synthesis of Learning }\end{array}$ & $\begin{array}{l}\text { All learning outcomes and skills come together in year } 4 \text {. This culminates in a major product design } \\
\text { project, final exhibition and portfolio of work. }\end{array}$ \\
\hline
\end{tabular}

skills in the Product Design programme (Table 1), it was identified that students received strong design skills education and produced ample innovative ideas and output from this, but that there was an opportunity gap with regard to turning design projects into commercially viable products and, more specifically, teaching the entrepreneurial skills required to do this.

To strengthen the programme there is a need for entrepreneurship to become an explicit learning outcome. Knowledge of entrepreneurship is particularly required for fourth-year students completing final-year major projects. Typically, these projects include designing a physical artefact to meet a user need. In identifying the type of entrepreneurship teaching that would complement this programme, we refer to Gibb (2007), who defines two approaches to learning to create an entrepreneurial person: 'The traditional business model' and 'Towards a broader societal model of entrepreneurship' (2007). The latter model is relevant to the design students in this case study, defining entrepreneurship in terms of the 'behaviours, skills and attributes needed to respond to problems and opportunities in the wider social environment' (Gibb, 2007: 105).

\section{Research design, scope and limitations}

In a move to reform and modernise European higher education in recent years, there has been a shift from traditional teaching-led to more learning- and student-centred curricula (Donnelly and Fitzmaurice, 2005). To place students' and other stakeholders' needs at the centre of module development, an inductive process of understanding those needs was required in this study. The Hilda Taba Model uses an inductive process in curriculum development, with the teacher involved in design and development. The first step in the process is identifying the needs of the learner (Taba and Spalding, 1962). Using this approach as a start, this paper outlines the commencement of a longer study seeking to understand the educational needs in entrepreneurship for design students. The findings at this stage will be derived qualitatively through interview and participatory co-design sessions with stakeholders.

At the time of writing, the module has just commenced. Therefore, a limitation in this paper is in the understanding of how the module was received by students in practice. Feedback will be received from learners and other stakeholders to assess content and iterate future module revisions. There were also limitations in participant recruitment due to time constraints in the study. Graduates with a longer work experience track record were contacted, but could not commit to the timeframe of the study. These participants will be involved in future module development. A focus group format was considered for co-design sessions; however, individual interviews were proven to work more effectively in organising around participants' work schedules.

The study uses the discipline of product design as a case study; however, its scope is relevant to other disciplines in design education, and indeed to any creative discipline. It also offers information for academic institutes seeking to implement entrepreneurship modules in existing creative programmes.

\section{Interview and co-design sessions}

The objectives of the study was to gain an understanding of learning outcomes and content for an entrepreneurship module for product design students and, with this understanding, to create a new module descriptor for implementation in an undergraduate design programme. To achieve this, individual semi-structured interviews were conducted in a co-design format with relevant stakeholders. This format was chosen as it allows the participants to openly voice their experiences and minimises the influence of the researcher (Creswell and Creswell, 2018) A co-design 
format was chosen as it encourages stakeholders to become part of the design process and can tap into their tacit knowledge and creativity to develop a shared vision for improvement (Moll et al., 2020; Shore et al., 2018).

To obtain an informed and holistic view of learning content, a range of participants was selected for interview, based on levels of experience. These ranged from management personnel (commercialisation and academic) to a design entrepreneur and a design graduate. The participant profiles were as follows:

- A design entrepreneur with an honours degree in Product Design. The participant had 8 years of entrepreneurship experience in new product development and had started two enterprises in this time.

- A head of a design education programme and a lecturer in a leading national university. The participant had 10 years' experience in both commercial design and academia.

- A head of an academic faculty of design. The participant had 12 years' experience of leading, creating and managing educational programmes and modules.

- A director of a university commercialisation centre. The participant had 20 years' experience of managing commercialisation activity and working with entrepreneurs in a leading national university.

- A design graduate. The participant had graduated from a product design programme and had 2 years' experience in the industry.

In total, five interview and co-design sessions were conducted. The main objective for participants was to assist in co-designing a potential new module. In designing these sessions, important consideration was given to ensuring a creative flow of ideas from participants. Therefore, the sessions did not follow a strict structure of formal questions; a semi-structured form of questioning was used to allow participants to openly contribute ideas.

An important aspect to be considered before conducting the research was that this module needed to complement an existing design programme. Therefore the interview and co-design findings needed both to support existing modules in the programme and to be easily implementable. To this end, a list of questions to facilitate the sessions was prepared based on the generic module descriptor format used by the institute. These questions included but were not limited to the following:

1. In your view, what skills do you think would make design students more entrepreneurial?

2. Post-graduation, what stages do our students need to focus on to make their design work more commercial?

3. What should be the aims of an 'Entrepreneurship for Designers' module be?
4. What could the possible learning outcomes be and what should the student be able to do afterwards?

5. What teaching methodologies do you think can achieve this? e.g. Lecturers, fieldwork, practicebased work, etc.?

6. How would a module like this be assessed?

\section{Analysis}

The interview and co-design sessions were audio-recorded and fully transcribed verbatim into Microsoft Word documents post-interview. During each session, quick sketch notes were taken by the researcher to assist with the validation stage of the session (Figure 1). In these notes, keywords, passages and themes were sketched and highlighted for synthesis and to assist analysis. For validation purposes, participants were asked to confirm the main themes and keywords after each interview.

In the next stage of analysis, the transcribed audio recordings were cross-referenced with the sketch notes to find overarching themes. To facilitate this, a card sorting exercise was conducted using Post-It Notes to create information architecture maps (Figure 2). Card sorting, according to Sherwin (2018), is a research technique to make sense of data, whereby topics are organised into groups using notecards. During the card sort exercise keywords were written on individual Post-It Notes and organised into themes and subthemes. Figure 2 illustrates the early stages of this exercise, showing the main themes of 'Practice' and 'Theory' emerging from the analysis. The process of card sorting was concluded when all keywords from the codesign sessions had been categorised into main themes.

\section{Findings}

The following is a commentary on the main findings of the research. It highlights the key themes that emerged from the analysis and factors to be considered in module development.

\section{Theme I: Overlap in design and entrepreneurship processes}

Reinforced throughout the research was the need for design students to have an explicit element of entrepreneurship learning in the programme, strengthening the requirement for a specific module to be created. Participants believed that there was a broad overlap between design and entrepreneurship processes and that confidence, belief, care and persistence should be the qualities of an entrepreneurial design graduate. In terms of process, it was stated that the module should teach the student to talk, listen and deeply understand real users. Moreover, this should be a reoccurring and iterative process through product testing with real users. A key aspect of the module should be to demystify what an entrepreneur 'is and 


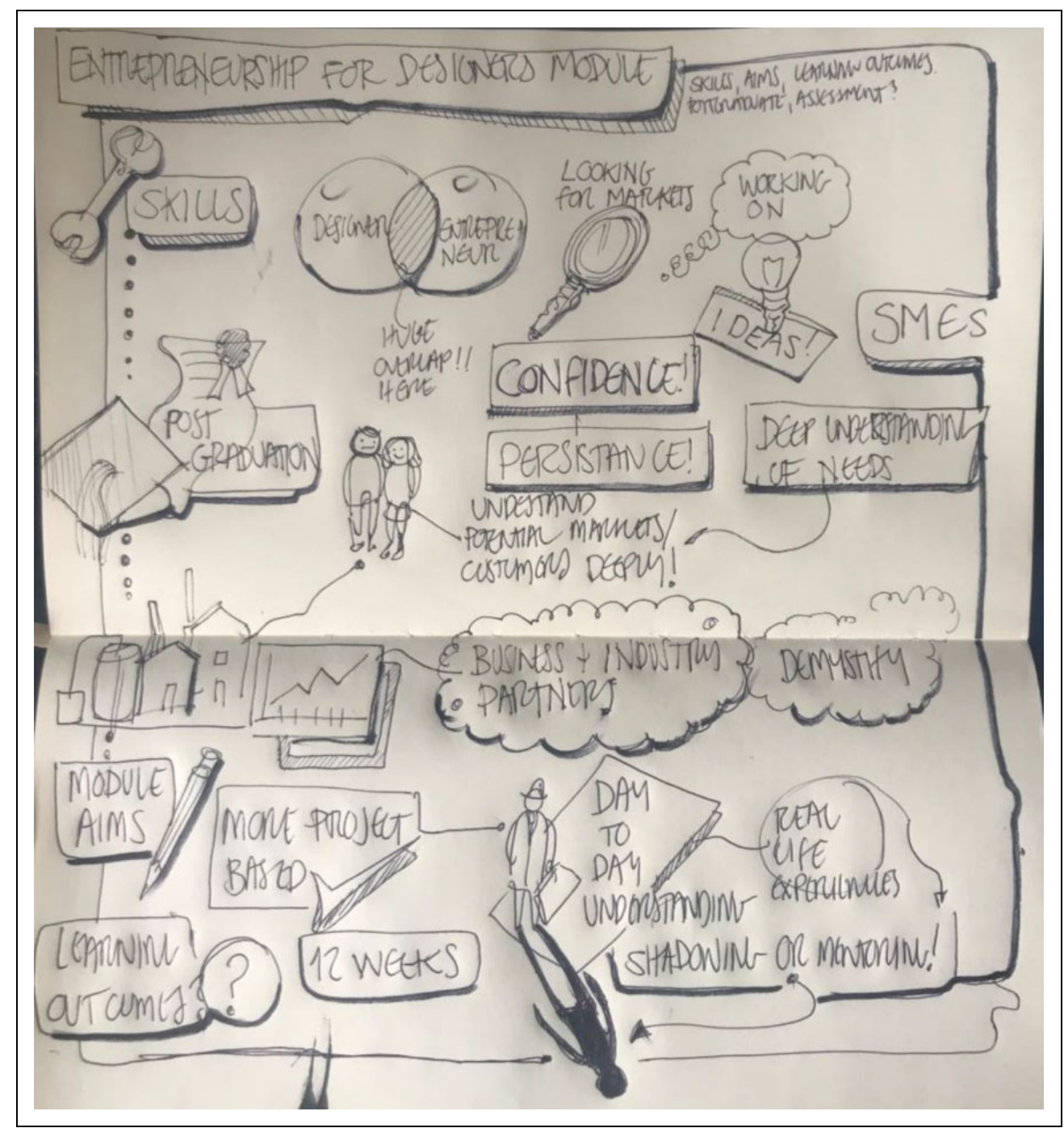

Figure I. Example of a quick sketch note documentation of a co-design session.

does', exposing the student to the day to day routine and understanding of real-life entrepreneurs. Current thinking indicates no specific link between the entrepreneur and their enterprise (Gartner, 1988). However, designers, not entrepreneurs, establish design enterprises (Design Council, 2005; Kennedy, 2009) and designers possess an individual approach to their creative work (Lupton, 2011; Schön, 1983) which is inseparable from the practitioner (Heller, 2008). Therefore, the designer is both the product offering and the enterprise this offers a different view of the entrepreneur in design than previously discussed (Kennedy, 2019).

\section{Theme 2: Practice through projects}

For design students, it was felt that the module should be less taught and theory-based, and more project and practice-based, to fit into a studio-based educational format. In addition, course content should be applied through exposure to entrepreneurial activity occurring throughout study - suggestions for this included using The Apprentice television show's format for an assignment. A participant heralded Sarasvathy's approach to effectuation and aligned it to design, noting that this should be the core theory to supplement applied project work:

... ensure that students are talking to potential real customers, end-users and industry/business partners. If I had somebody back in university who had a route to market with similar products that could give advice and confidence, that would've been fantastic. It's what a good designer should be doing anyway... listening to customers, co-creating, and going back numerous times to get feedback. (Design graduate)

\section{Theme 3: A mix of skillsets}

The interviewees believed that entrepreneurial design graduates required a particular mix of skillsets, namely selling, 


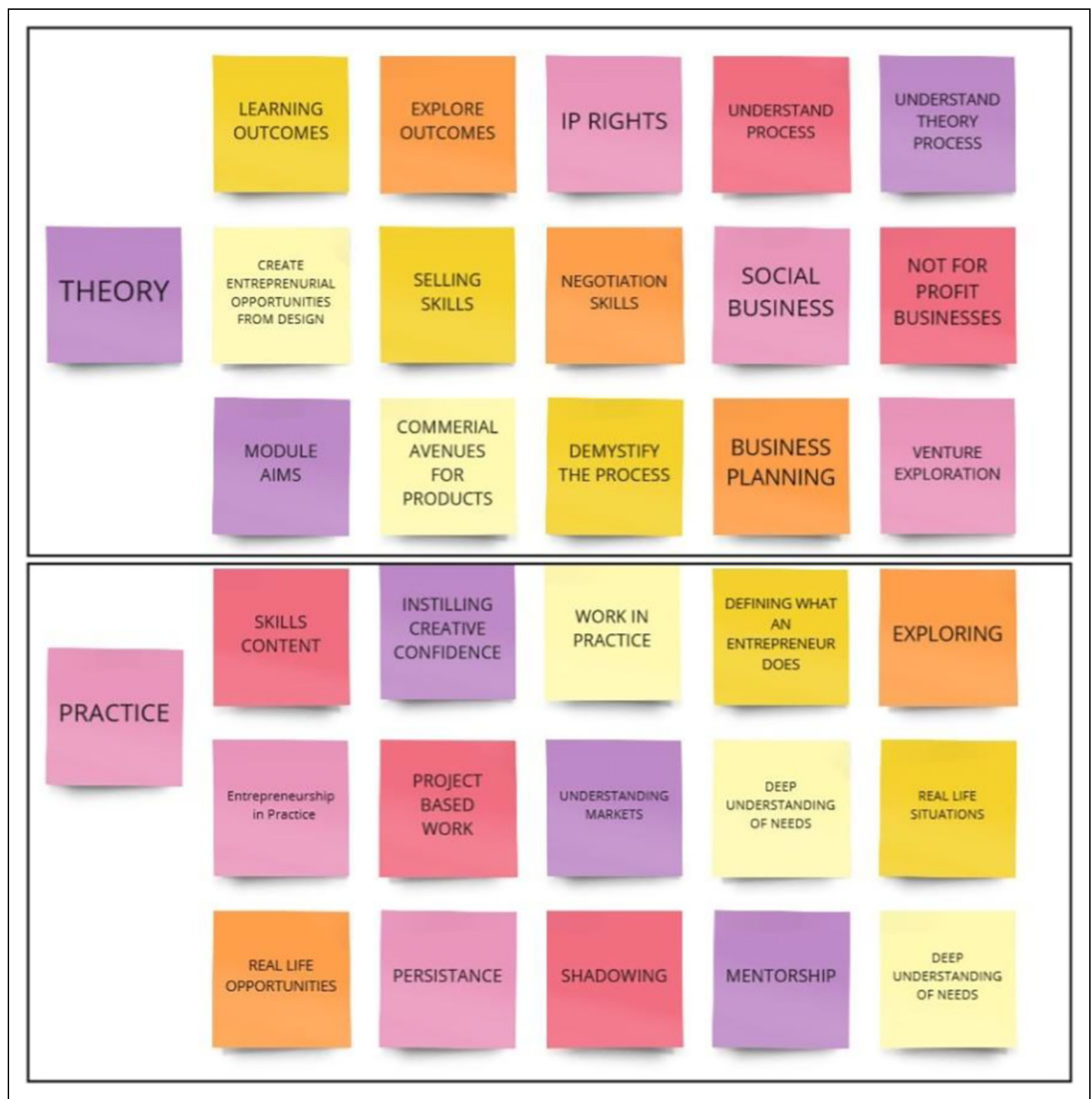

Figure 2. Early-stage iterative card sorting: Identification of keywords in the process of developing an information architecture map. The figure shows the main themes of 'Practice' and 'Theory' emerging from the card sorting analysis.

negotiation, leadership and team building, and financial and business planning skills. Together with these skills, they needed to understand commercial viability and how to select the correct business model. Importantly, it was suggested that students needed to critically evaluate how design innovation could add value to an organisation. It was believed that they needed to consider strategy, internal structure, processes, resources and core competencies, and to be able to develop strategies for planning and implementing successful innovations. Furthermore, they should be asked to diagnose the core problems of a business related to design innovation and formulate proposals to deal with them. It was suggested that this could be achieved through a mixture of lectures and practice-based project work, all conducted through continuous assessment in group and individual projects.

In terms of learnt skillsets, it was suggested that intellectual property/ownership and dealing with finance when starting up a business should be included. Associated abilities were those of drafting a business plan and understanding the different legal entities. The participants stressed that students 'need to know before they do' therefore it was important to first have lectures covering entrepreneurship theory and afterwards to ensure that the module was applied through practice-based learning - for example, the stages of bringing a product to market. From an implementation perspective, it was thought that this module would 
Table 2. Page I of the descriptor for the 'Entrepreneurship for Designers' module, outlining aims and learning outcomes.

MODULE TITLE: Entrepreneurship for Designers

Total Student Workload (per module)
Lectures/Studio-based learning

best suit third-year students in their second semester. It was noted that developing confidence and the ability to look past risk were perhaps difficult to teach students; however, it was thought that this should be attempted:

... it is all about giving students confidence and offering examples of practice and knowledge to bring their ideas forward. Lots of students have great ideas and I'm not sure what stops them moving on. Confidence is a big thing. You can get the knowledge but it's about confidence and looking past risk. (Management participant)

A central theme in entrepreneurship theory is the concept of 'risk' and 'uncertainty'. Knight (1921) discussed the importance of 'uncertainty' in detail and distinguished genuine uncertainty from risk, the latter being insurable because of the probabilities of possible outcomes. In contrast, the former (uncertainty) is uninsurable because neither the outcome nor the probabilities can be defined (Grebel, 2004). However, not all risks are equal, and some risks are less risky than others, which may offer insight into how and why entrepreneurs take different types of risk at different times. Entrepreneurs must be able to deal with risk to cope with unknown elements and need the skills and competencies to do so.

\section{Module content}

The interviews resulted in a broad understanding of the content to be included in an Entrepreneurship for Designers module. Drawing on these interviews the following content was put forward and detailed in a module descriptor.

\section{Entrepreneurship for Designers: Theory}

The module will commence with theory, defining forms and processes of entrepreneurship and its relationship with design. For this, examples of design innovations through social, technology and profit-based entrepreneurship would be discussed. Processes of entrepreneurship would then be outlined through causation and effectuation. Effectuation will then be brought into focus. Comparisons with design will be discussed, such as human problem-solving and evolving goals gradually and creatively (Sarasvathy, 2014). Further theory on designers' intellectual property rights (copyright, trademark, patents, industrial designs and related rights) and the commercial viability and finance of new product development and businesses will be taught. As a resource, the book Business Model Generation offers a creative and visual means of creating business models for entrepreneurial designers (Osterwalder and Laurent, 2010). In the interviews, business planning was outlined as an important element in this module. However, rather than the traditional approach to the business plan, Beyond the Business Plan (Bridge and Hegarty, 2013) offers a complementary approach to the design process and effectuation. This book offers a less prescriptive means of writing a business plan, suggesting 10 principles in venture exploration. 
Table 3. Page 2 of the descriptor for the 'Entrepreneurship for Designers' module, outlining content, teaching and learning strategies and assessment.

\section{SYLLABUS \\ CONTENT}

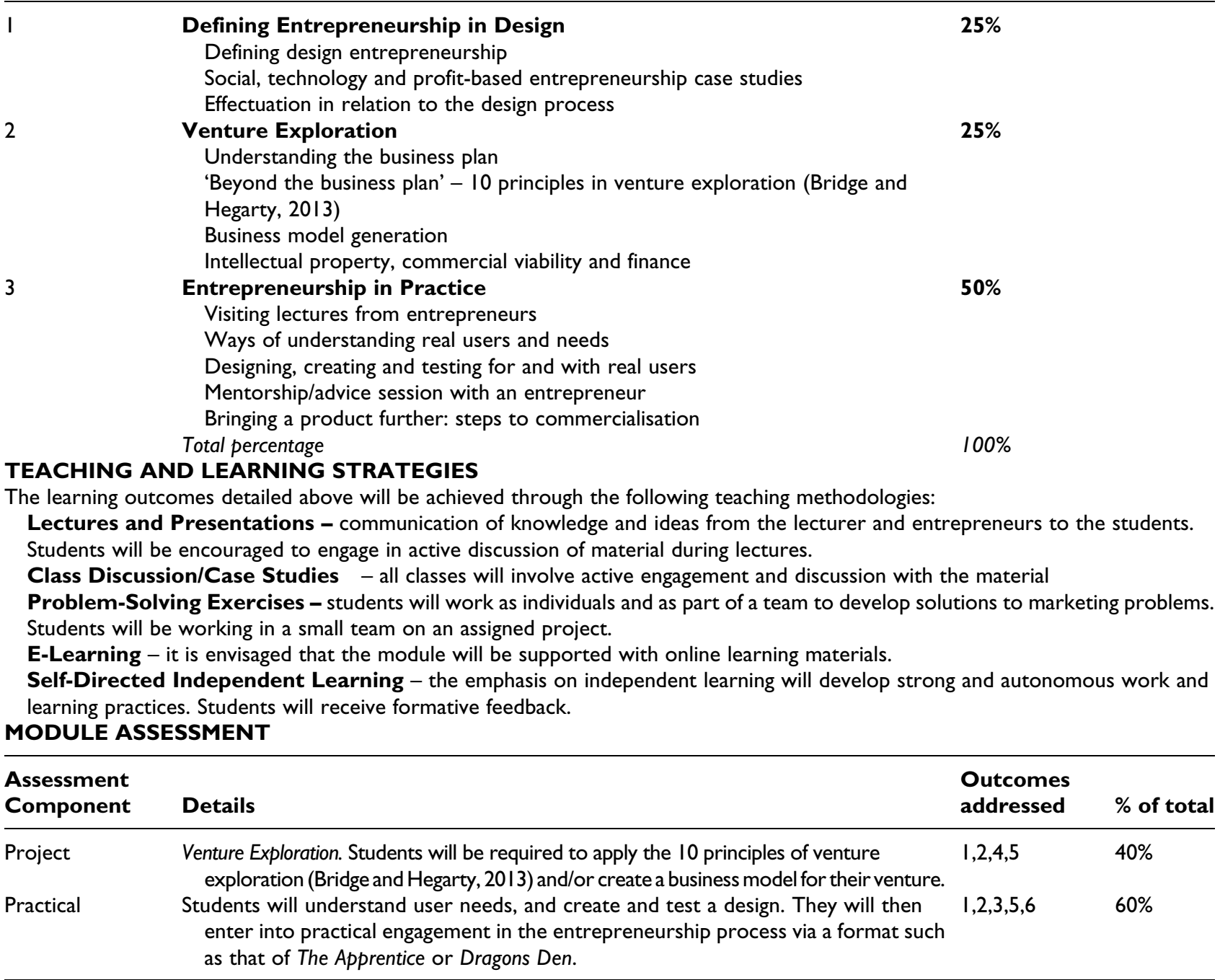

\section{Entrepreneurship for Designers: Practice}

Practice-based work will be an important element of the module. The main intent of practice would be to demystify entrepreneurial activity. To facilitate this, lectures or presentations by visiting entrepreneurs will be delivered. A practice-based project will be included as a core part of the assessment. This project will involve the student exposing a design idea to a market, first by talking, listening and deeply understanding real users' and needs and, second, by designing, creating, prototyping and testing with real users. In addition, selling skills and negotiation skills will be established by conducting assessment in a format following that of the TV programmes Dragons' Den or The Apprentice. Leadership and team-building skills can be achieved by giving assignments to groups. 'Mentorship' or advice sessions will be conducted with visiting entrepreneurs.

\section{Module descriptor}

To bring the research to the next stage of creating a module descriptor, an open coding process was used to analyse the data (Creswell and Creswell, 2018). To facilitate this, an institute module descriptor template was used to synthesise information into a working document. The data were first sorted into the main themes of Aims, Learning Outcomes, Syllabus Content, Module Assessment, and Teaching and Learning Strategies. This aided categorisation of the data and a starting point from which to draft the module. Following this, an iterative process of reading, re-reading and 
drafting revisions was undertaken. Tables 2 and 3 outline the results of this process.

\section{Conclusion}

The objectives of the study were to gain an understanding of learning outcomes and content for an entrepreneurship module for product design students and, with this understanding, to create a new module descriptor for implementation in an existing undergraduate product design programme. This paper offers a rationale for the embedding of entrepreneurship learning in undergraduate design programmes. It explains that Design Thinking and entrepreneurship are complementary processes, and that skills in entrepreneurship can enable students to follow commercial opportunities after graduation. In the case study, it is identified that entrepreneurship learning was a missing element in the undergraduate design programme and that it should have an explicit learning outcome. Interviews with relevant stakeholders provided information on the appropriate content for an 'Entrepreneurship for Designers' module. Delivered through practice and theory, this module will clarify the entrepreneurship process through the lens of a designer and will provide students with the confidence to pursue design-related ventures. A module descriptor was created to outline the aims, content and learning outcomes. With regard to fitting it into the existing programme, the module replaces two design practice studio hours per week, on the basis that it will help to integrate design practice and entrepreneurial activity.

Similar research should be conducted to embed entrepreneurship learning in other undergraduate creative programmes. Embedding this at an early stage will enable entrepreneurial culture and innovative research output to grow.

\section{Declaration of conflicting interests}

The author(s) declared no potential conflicts of interest with respect to the research, authorship, and/or publication of this article.

\section{Funding}

The author(s) received no financial support for the research, authorship, and/or publication of this article.

\section{ORCID iD}

P.J. White (D) https://orcid.org/0000-0002-5716-8643

\section{References}

Barron F (1988) Putting creativity to work. In: Sternberg RJ (ed.), The Nature of Creativity: Contemporary Psychological Perspectives. Cambridge: Cambridge University Press, pp. 76-98.

Bridge S and Hegarty C (2013) Beyond the Business Plan: 10 Principles for New Venture Explorers. London: Palgrave Macmillan.
Brown T (2009) Change by Design - How Design Thinking Transforms Organizations and Inspires Innovation. New York, NY: Harper Collins.

Bruner JS (1961) The act of discovery. Harvard Educational Review 31: 21-32.

Creswell JW and Creswell JD (2018) Research Design: Qualitative, Quantitative, and Mixed Methods Approaches, 5th edn. Los Angeles, CA: SAGE.

DCCoI (2015) Ireland the Design Island. Available at: http:// www.dccoi.ie/content/files/National_Design_Strategy_ ISSUU.pdf (accessed 12 January 2020).

Dempsey H and White PJ (2015) A Culture of Universal Empathy in Design at the Institute of Technology Carlow. Universal Design in Education Conference, Dublin, Ireland, 12-13 November 2015. Available at: https://arrow.tudublin.ie/cgi/ viewcontent.cgi? article $=1003 \&$ context $=\operatorname{exdes} 3$.

Design Council (2005) The Business of Design. London: Design Council.

Design Council and DBA (2005) The Business of Design: Design Industry Research. London: Design Council.

DJEI (2016) Policy Framework for Design in Enterprise in Ireland. Dublin: Department of Jobs, Enterprise and Innovation.

Donnelly R and Fitzmaurice M (2005) Designing modules for learning. In: O'Neill G, Moore S and McMullin B (eds) Emerging Issues in the Practice of University Learning and Teaching. Dublin: All Ireland Society for Higher Education (AISHE), pp. 99-110.

Enterprise Ireland (1999) Opportunities in Design. Dublin: Enterprise Ireland.

Gaiardo A (2019) Entrepreneurship and innovation design in education. An educational experience to train the new entrepreneurial designers. The Design Journal 22(Suppl 1): 203-215.

Gartner WB (1988) "Who is an Entrepreneur?" is the Wrong Question. Baltimore, MD: University of Baltimore.

Gaynor L, Dempsey H and White PJ (2018) How design thinking offers strategic value to micro-enterprises. Paper presented at the Design Research Conference - Design as a Catalyst for Change, Limerick, Ireland. Available at: https://bit.ly/ 2UU6cgx.

Gibb A (2007) Entrepreneurship: unique solutions for unique environments. Is it possible to achieve this with the existing paradigm? International Journal of Entrepreneurship Education 5: 93-142.

Grebel T (2004) Entrepreneurship: A New Perspective. Abingdon: Routledge.

Gunes S (2012) Design entrepreneurship in product design education. Procedia - Social and Behavioral Sciences 51: 64-68.

Head BW (2019) Forty years of wicked problems literature: forging closer links to policy studies. Policy and Society 38(2): 180-197.

Heller S (2008) The Design Entrepreneur: Turning Graphic Design Into Goods That Sell. Newton, MA: Rockport.

Innovation Taskforce (2010) Report of the Innovation Taskforce. Dublin: The Stationary Office. Available at: http://www.eban. 
org/wp-content/uploads/2014/12/Irish-Innovation-TaskforceFinal-Report-March-2010.pdf (accessed 12 September 2020). Intertrade Ireland (2009) A Study of the Design Services Sector on the Island of Ireland. Dublin: Intertrade Ireland.

Kennedy C (2009) Benefits of Continuing Professional Development in the Visual Communications Sector in Ireland. Dublin: Technological University Dublin.

Kennedy C (2019) Design as Entrepreneurship: Towards a Design-Specific Entrepreneurship Framework. TU Dublin 10th Annual Graduate Research Symposium, Dublin, Ireland, November 2019.

Knight F (1921) Risk, Uncertainty and Profit. Boston, MA: Houghton Mifflin.

Kolb DA (1984) Experience as the Source of Learning and Development. Hoboken, NJ: Prentice-Hall International.

Lupton E (2011) Graphic Design Thinking. New York, NY: Princeton Architectural Press.

Marston HR, Shore L and White PJ (2020) How does a (smart) age-friendly ecosystem look in a post-pandemic society? International Journal of Environmental Research and Public Health 17(21): 8276. DOI: 10.3390/ijerph17218276.

Moll S, Wyndham-West M, Mulvale G, et al. (2020) Are you really doing 'codesign'? Critical reflections when working with vulnerable populations. BMJ Open 10(11): e038339.

Osterwalder AP and Laurent YS (2010) Business Model Generation: A Handbook for Visionaries, Game Changers, and Challengers. New York, NY: Wiley.

O Sullivan J (2019) Future Jobs Ireland, and the National Skills Strategy 2025. Dublin. Available at: https://www.education.ie/ en/Publications/Policy-Reports/pub_national_skills_strategy_ 2025.pdf (accessed 12 August 2020).

Robinson K (2011) Out of Our Minds: Learning To Be Creative. Oxford: Capstone.

Sarasvathy S (2014) Society for effectual action. Available at: http://www.effectuation.org/learn/effectuation-101 (accessed 12 January 2020).

Schön D (1983) The Reflective Practitioner: How Professionals Think in Action. New York, NY: Basic Books.
Scott S and Venkataraman S (2000) The promise of entrepreneurship as a field of research. Academy of Management Review 25(1): 217-226.

Sherwin K (2018) Card sorting: uncover users' mental models for better information architecture. Available at: https://www. nngroup.com/articles/card-sorting-definition/ (accessed 12 September 2020).

Shore L, Kiernan L, DeEyto A, et al. (2018) Older adult insights for age friendly environments, products and service systems. Design and Technology Education: An International Journal 23(2): 40-58.

Taba H and Spalding WB (1962) Curriculum Development; Theory and Practice. Professional Education for Teachers Series. San Diego, CA: Harcourt, Brace \& World.

Torrance EP (1963) Creativity. Washington, DC: National Education Association.

TU Dublin (2021) Design - visual communication. Available at: https://www.tudublin.ie/study/undergraduate/courses/designvisual-communication-tu973/ (accessed 24 January 2021).

Vrkljan B, Whalen A, Kajaks T, et al. (2019) Creating an intergenerational university hub: engaging older and younger users in the shaping of space and place. Gerontology \& Geriatrics Education 40(2): 244-260.

White PJ (2012) Designer as ethnographer: a study of domestic cooking and heating product design for Irish older adults. $\mathrm{PhD}$ Thesis, National University of Ireland Maynooth. Available at: http://mural.maynoothuniversity.ie/4740/1/PhD\%20Thesis_ PJ\%20White.pdf (accessed 12 September 2020).

White PJ (2013) Ethnography in Design for Older People. Paper presented at the 2nd European conference on design 4 health, sheffield. https://core.ac.uk/download/pdf/34614893. pdf\#page $=62$ (accessed 22 April 2021).

White PJ and Deevy C (2020) Designing an interdisciplinary research culture in higher education: a case study. Interchange 51(4): 499-515.

White PJ, Marston HR, Shore L, et al. (2020) Learning from COVID-19: design, age-friendly technology, hacking and mental models. Emerald Open Research 2(22). DOI: 10. 35241/emeraldopenres. 13599. 